\title{
The Impact of Linguistic Diversity on the Social Justice and Equity Pedagogy to Knowledge Construction
}

\author{
Assist. Inst. PhD. ABD. Heyder Sabir Hasan \\ Department of English Language, College of Languages, Salahaddin University, Erbil, \\ Kurdistan Region, Iraq \\ heyder.hasan@su.edu.krd
}

\section{Prof. Dr. Ali Mahmood Jukil}

Department of English Language, College of Basic Education, Salahaddin University, Erbil, Kurdistan Region, Iraq

ali.jukil@su.edu.krd

\section{ARTICLE INFO}

\section{Article History:}

Received: $17 / 12 / 2020$

Accepted: 25/2/2021

Published: Winter 2021

Keywords: $L D$, social justice, Equity

Pedagogy, identity and Knowledge

Construction

Doi:

10.25212/Ifu.qzj.6.1.29

\section{ABSTRACT}

Linguistic Diversity (LD) refers to linguistic variety. Here, it refers to the students' functional linguistic or sociolinguistic academic and non-academic linguistic variation. Also, social justice and equity pedagogy are the representations of equal opportunities that ensure equal and constant development which leads to knowledge re/constructions.

Ecologically in and out of the institutional settings of Humanity Sciences studies (HSs) the situation is diverse linguistically and sub/culturally. The problem is that the humanity sciences students are supposed to be linguistically and professionally proficient and knowledgeable but the language policy, plan and practice do not assist them to reach their higher education standards.

So the questions are: Is LD implemented properly? Does the LD lead to knowledge re/construction and development? How is the social justice and equity pedagogy in the processes of teaching, leaning and classroom management?

The hypothesis is that the LD is not implemented as it is and as the requirements and needs of students. So the graduates might not be skillfully and academically prepared locally, nationally and internationally. 
The study aims at finding the sociolinguistic diversity obstacles that affect teaching, learning and developmental knowledge construction via the investigation of the degree of social justice, equity pedagogy and distinctive individuals' identity.

A questionnaire was constructed on the basis of the correlated contents of the study and some absolutely related resources. The items ask the quantitative and qualitative attitudes and perspectives of the senior students who are towards the topic.

The participants are the seniors at the HSs at Salahaddin University- Erbil (SU-E) who are diverse linguistically and culturally. Their attitudes can be reliable and valid because they had had experiences the university learning process strengths and weaknesses.

It has been confirmed and concluded that the de facto or LD praxis of implementation requires more accurate related techniques of teaching, learning and socialization processes. Because the students approve that they are not actively and skillfully learnt the academic languages, also, problems of social justice and equity pedagogy so that it does not help the students to have the ability to comprehend the contents of the curricula and have the ability to enroll in the lifelong national and international developmental knowledge reconstruction and creative constructions, careers of marketing and academic professional proficiencies.

\section{1-Introduction}

The modern national and global relationships, interactions, and communications provide extreme significance of the LD, social justice and equity pedagogy in the field of basic and higher education knowledge re/construction and development. Here, theoretical issues of the study are provided. Also, the study reviews and conducts both qualitative and quantitative practical approach of researching so as to solve the HSs weaknesses and problem that imped the regular linguistic and knowledge achievement. 


\subsection{Diversity}

Diversity refers to variety, it is classified as: First 'primary dimensions' such as race, sexual orientation and gender, age, cast or class, physical (dis)ability (mental or physical), and ethnicity, learning styles and intelligences; as well as, 'secondary dimensions' such as income or socioeconomic class, education, work or profession, religion, LD, geographical location, martial and parental status etcetera. Diversity is the ideology of recognizing and promoting multiculturalism that involves multilingualism in linguistically diverse societies (Richards, 2002; Cruz et al, 2014, p.13; Lim \& Able-Boone, 2005, cited in Lim, 2006, p.10; Janssens and Steyaert, 2003, pp. 4-5). Jha (2007, pp.33-43) says that the policy of inclusion is to a moderate degree is not the answer to equal education, because the barriers to access are not only physical and structural but also include the curriculum, pedagogy and tests or examinations such as in LD society the students first language or variety is not used in the school or university education, an example is the requirement of proficiency test for academic and even vocational studies or even job seekers.

In a multicultural university the cultural diversity should be recognized including linguistic, religious holidays, inspiration via various teaching methods, students' participation and equal opportunities in learning and fair assessments, it should avoid discriminations and harassments (Gosling, 2003, p. 179-80). Language is regarded as one of the most instant and sensitive signs or measures of diversity. A difference in language betrays someone's social class, regional, gender and cultural backgrounds that puts individuals in or out of a group, community, and nation (Blommaert, 2013, p. $1 \& 11)$. In this regard, the worldwide protection of rights and identities was declared in Article 2 of the Universal Declaration of Human Rights (2015):

"1.Everyone is entitled to all the rights and freedoms set forth in this Declaration, without distinction of any kind, such as race, colour, sex, language, religion, political or other opinion, national or social origin, property, birth or other status. 2.Furthermore, no distinction shall be made on the basis of the political, jurisdictional or international status of the country or territory to which a person belongs, whether it be independent, trust, nonself-governing or under any other limitation of sovereignty". 
So, international legislation of rights obliges the admittance, acceptance and respect of diversities and LD.

\subsection{LD}

The philosophy of LD originates from the notion of coincidences and existence of various languages peoples in places and in times. It implicates the study of cultures which involves the study of culture and LD as a basic specific of human being. And, effects of economic, social, political, cultural, tools or technological and linguistic ramifications, these consequences and the process of globalization affects the languages and especially the minority languages in the world. Also, the data of studying such LD comes from language policy and planning, teaching and learning, multilingualism and sociolinguistics. (Crystal, 2015, p.2-4).

LD as a crucial dimension of diversity is used as a concept for various purposes in linguistics and education. First, it refers to the differences and diversities of linguistic items in/of languages. Second, it refers to languages or socioLD, in which it refers to different languages or varieties used differently in different contexts for different purposes according to the factors of formal or informal, home, academic language/s of school, higher education or other institutional settings, religion, political etc. So, there are opinions about what exactly the term LD means; as it is related to linguistics, anthropological linguistics, and sociolinguistics, unless, the terms LD and socioLD are alternatively used by different scholars. On one hand, in contrastive linguistics, there are four ways: 1 the relationship is either historical/ genetic i.e. languages of the same family ancestry such as Kurdish-Persian; 2 areal, i.e. the effect of neighbouring languages on each other (language contact) such as the contact, mixture and switch between Kurdish, Persian, Aramaic, Arabic, Turkumani and English; 3 typological i.e. morphological of isolating, agglutinating, or fusional languages; and 4, syntactic i.e. subject first, verb first, or object first or their structure or position of transitivity, object, subject, and voice. Here, the concept of LD is called Linguistic or Formal Typologies of languages. On the other hand, the concept refers to a number of languages or verities in a sociolinguistic context of language status of use, in which 
some attributes or features demonstrate the diversity, they are standardization, vitality, historicity, autonomy, reduction, mixture and de facto norms, so, here the concept of LD refers to various languages / varieties of languages used in a society or community, in this regard, the term is called Sociolinguistic or Functional Typologies of languages (Aitcheson, 1999, pp.162-73; Lazard, 2005, pp1-15; Bell, 1976, pp.147152; Nettle, 2002, pp. 5-14). This study deals with the functional typologies of academic languages implemented in the higher education.

\subsection{Approaches to Linguistic Diversity}

Nevez (2006, pp. 16-71) collects seven main theoretical approaches to LD from the literature, they are as follows:

1-Instrumental Approach focuses on the functional aspects of language as a tool for communication purposes of encoding and decoding or transmitting meaning via words and sentences or linguistic items. So, languages are valued on the basis of their written structural influences that can be studied without their speakers such as Latin and Sanskrit descendants. Language contact is regarded as the instrumentalist approach as well, so that, people of minority or less used languages try to protect and promote their languages through media, curriculum of institutional settings and literature processes. One criticism here is that instrumentalist approach sees language as neutral and not used as a tool of identity but a tool of language awareness. 2-Ethnocultural Approach is the language as the identity of minority groups' ethnicity, culture and race. Ethnicity sometimes has disempowerment, pejorative or ethnic-cleansing meaning while ethnocultural identity has a positive meaning of socio-cultural traditions in relation to the majority culture. So, ethnicity refers to including some and excluding others, while ethnocultural refers to the altogether inclusion ideology. A historical cultural language is regarded as the means of expressing individuals and community identity, cultural greetings, proverbs, idioms, riddles, traditional stories,...are only expressed via language, without language the ethnocultural does not exist. 3-Ecological Approach is the physical- 
biological relationship of environment with a language and with other surrounding languages. An ecological approach to LD comprises the development of ecological or biomorphic to prove perceived similarities between linguistic divergence and convergence in other words language death, living languages and mother tongues, to discover the position of languages in the natural environment or world. Any change in biological environment such as earthquakes, deforestation...and sociobiological change such as urbanization, industrialization, technology, displacement... affect LD change. 4-Language rights Approach is the social and communication rights, the right of using languages freely in both oral and written communication, and not being discriminated on the basis of this use. Here, language is not only considered as means or instrument of communication but also as a category of individuals' and groups' cultural inheritance, life style and identity. As the International Covenant on Civil and Political Rights, (1966) Part III, Article 27. Declares that:

"In those States in which ethnic, religious or linguistic minorities exist, persons belonging to such minorities shall not be denied the right, in community with the other members of their group, to enjoy their own culture, to profess and practise their own religion, or to use their own language".

5-Economic Approach refers to the effects of learning additional languages on economy or vice versa, learning supper-central layered languages is better than the central and peripheral layered languages while learning the hyper-central layered, which is English is the best for investments and businesses. The legitimacy and hegemony of economic model on language learning and use it in conceptualizing identity, i.e. the discourses of learning languages for highly self-conceptualization. 6Political Approach deals with discourses of language and power, the power is both expressed via language itself and some languages are regarded as powerful over the other peripheral or not prestigious once. Ideologies such as communism, theology, and capitalism use power via language politically. Language is considered as the sociosymbolic power between the individual and different language group speakers. 7Post-structural Approach opposes the assumption that languages are pre-existing, distinct objects, transcendent of speakers of languages. Instead, the approach 
proposes that languages are produced in different ways, in a complex connection of identity, power, and diverse systems of cultural and linguistic expression. In this regard, language is not a static knowable organism or object. Rather language is a form of expression, a process that is habitually perfomative, contingent, transgressive, and in a continuous development or flowing. So, the minority languages are either subjected to deterritorialisation or reterritorialisation processes of language promotion.

Other than these seven approaches, there is the academic languages approach. 8Academic Languages Approach, other than Nevez's research of the approaches to LD, it can be said that there is an Academic Approach, Academic languages at university can be counted as independent systems of sounds, structure or morpho-syntax, meaning or semantics and pragmatics, discourse (written and oral), power and solidarity, socio-cultural and socio-symbolic, their ways of teaching and learning, and standardization and functions. Academic or institutional language is a concern of educational linguistics; it is different from domiciliary, home or real languages. Halliday (2007, pp.356-7) says that academic language/s is regarded as a variety in itself learnt and used in spoken and written forms progressively regarding spelling, grammar, and composition. It might be the first, second or foreign language of the students and teachers, it is used for studying, learning and teaching other subjects i.e. it is used as the medium of education or as a subject at schools and universities, it creates its own world of experiences. In this case, language is somehow separated from culture. It also creates different kinds of knowledge depending on generalizations and concepts that are detached from daily life and related directly to the learners own experiences, so it is the language of curriculum genres. Huszti (2013) states that academic language in variational linguistics is defined as a variety of contextual factors, as a distinct register and genres of language identical to jargon (profession words and expressions) applied in the teaching, learning and curriculum of academic courses of universities and schools.

\subsection{The International Hierarchy of Languages}


Not only varieties of a language, as (Hudson, 1996, p.32-3) presents, but also the languages of the world are graded on the basis of power of more or less use. (Abram, 2001) cited in (Piller, 2016, p.14-5) grades the nearly 6000 languages of the world into certain strata or layers, the first layer is the peripheral languages estimated to be around \%98 of the world's languages used for local communications, the second is the central layer which are official languages of the nations that are used for political and bureaucracies, while the third is the super-central layer which are used for international communication of long-distances. Finally, on the top, is the hypercentral language which is English, used for global communications. The system and connection of these layers is a pyramid-like, and the superior the communicative spread of a language, the more cherished and prestigious the language is. In this regard, English language as an international, academic and non-academic means of communication has the hyper-central role, Arabic has also the super-central role in the Muslim world, Kurdish as majority language has the central role in Kurdistan.

\subsection{Linguistic Diversity and Identity}

Nasir et al, (2016) cites some raising issues and theories from researches on the oppositional identities, stereotype threat, exclusion, the relation between classroom structures and identities, plus the relations between ethnic identity, language proficiency, and academic achievement, about the African, Asian, Latino, and white students in the USA, concluded that the diverse cultural, racial/ethnic, and linguistic identities affect language and academic professional proficiencies, achievements, health and psychological wellbeing, social and educational engagements. Similarly, Gosling (2003, p.163-4) prove that students' learning is shaped by their multiple identities such as gender, age, sexual orientation, ethnicity, class, nationality, past experience, educational experience, achievements, self-perception, goals, abilities and disabilities, languages, and social relationships. Murray and Christison (2011, p.4) cite that research on learning and language show that identity is formed, dynamic, also transformed via language learning and teaching processes, besides, people either attempt to affiliate with or alternate their identity in a group or nation so that they can stay in, or, keep their language or variety to have retain with their native community. Both cases produce problems for individual's identity. Thus, a society of 
multi-groups and individuals identities provides various and more powerful knowledge to the ground of education in general and knowledge construction in particular.

\subsection{The Challenges and Solutions of Linguistic Diversity}

The advocate of LD leads to a sort of nation within a nation policy which lacks the possibility and creates the separation and sets people apart under the cultural pride false guise. Also, the implementation of LD in education costs much amounts of the national economy because it requires extra teachers, materials and classrooms. It is also said that LD costs the economy of the state. So, it is preferred to support autocracy of language practice in education over democracy (Commins \& Miramontes, 2005, p.107-9). In contrast, as it is explained so far, it is better to design the LD approach of teaching, learning and curriculum on the basis of peoples' languages to make them united not the unity i.e. to accept and respect the diversities with regard to coexistence of the diverse people. In order to avoid separation, cultural isolation and the promotion of a language at the expenses of other languages in a country or region the policy makers and decision makers are supposed to provide the free language courses according to the students' or learners' wishes and needs at higher education settings. Also, economically, the cost of monolingualism and multilingualism are not too much different.

\subsection{Internet Linguistic Diversity}

Internet has fewer roles in language change and a greater role in fostering language presence. It offers home for all languages but at first it was dominated by English language speaking and writing discourses so that the Roman scripts were the only writing symbols. Essentially, internet is regarded as an outright democratic technology for cultural and LD, but there are some problems. At the beginning, the growth or penetration was with the non-Roman scripts and along but then the top ten languages such as Chinese and Spanish. Gradually, other languages have had right of entry and use. So the poor nations and languages of less prestige, smaller size, unaccepted or less elaborated of functions were neglected either politically or technically i.e. because of the lack of the internet and written language penetration 
access. The majority of languages of minorities could not use internet for local, national and international communications, teaching, learning and testing their languages (Crystal, 2011, pp.78-91). Nowadays, Arabic, Kurdish, Turkumani, and Syriac languages have written and spoken access on internet. But, their communication uses still need to be fostered.

Internet has the features of capacity, speed, automation, communicability, provisionality, replication, interactivity, multimodality, and non-linearity. it can network schools and universities nationally and internationally, it has operational roles in teaching, learning and testing both content and language objectives, it allows individuals and groups work and cooperation, it boosts recall, thinking and affective powers of learning (Pritchard, 2007, pp.1-26). Internet has very effective roles in teaching, learning and researching as an important technique of knowledge construction at higher education.

\subsection{Linguistic Diversity and Equity}

All languages and varieties are complex, rule-governed and reveal diverse set of structural patterns, so, they are linguistically equal except for the selection, codification, and elaboration of function. One problem or question is that whether the linguistic implementation is descriptivism or prescriptivism (Sampson, 1980, p. 76-7); both approaches have problems in the implementation process. e.g. is there any aspects of students' first language in the curricula teaching and learning, and another problem is the individual speakers' normal and abnormal language leading up to prejudices and inequalities; in language production, the differences between the people of even the same age in the type and range of academic or non-academic vocabularies, syntax or sentence construction, skills in using speech in certain tasks and the arts or style of reading and writing because linguistic inequality is a cause of social inequality, i.e. social inequality is a consequence of linguistic inequality, this phenomenon is perpetuated and descended, thus, linguistic equality is relevant to the whole of language and its use.

Socially, there are three types of inequalities: First, subjective inequality i.e. people are thinking about each other's language, whether a language or variety is thought to be right or wrong. Certain people in some communities are credited with various 
amounts of friendliness, intelligence, merits or opportunities, rights and other such benefits based on the way of they speak. This type of inequality involves languagebased prejudice, it is a person's prejudice, underestimation or overestimation of drawn conclusions about other people's character or personality, and abilities based on the 'how' or 'way' that individual speakers only, regardless of the 'what' or contents of the speaking. Such discriminations based on accents of lower-class and upper-class. A case, when only hearing 'gossip' about other people, prejudices are made in which hearers rely on the guesswork only, the reason, as an act of identity, when people speak or write they socially put themselves in a multi-dimensional space. Also, Evaluation of language, talk by itself is neutral, it is a clue to social exchange of information, but people usually evaluate other persons' speech to be good or bad, when a group or a community thought to be tough their accent or dialect is stereotyped to be tough also. A stereotype is an overall fixed image or set of characteristics that many people believe denote particular type of person or thing, if $X$ is certain characteristics of language and $Y$ is certain characteristics of personality, language will be clue to personality whether this stereotype is positive or negative. The fixed stereotypes of teachers and students in the process of education lead to prejudices or some kinds of biasness towards certain phenomena in the evaluation and decision making. Second, is linguistic incompetence: strictly linguistic inequality i.e. to what extent the speakers know and aware of the sounds, words and structures of their languages. The Chomsky's view of competence or individual's specifically linguistic knowledge and performance or language presentation explains this type of inequality, the child language, home language and academic languages. Third is communicative incompetence: inequality in communication i.e. not only the knowledge about language but also the knowledge and ability how to use language which is communicative competence, i.e. to say what, to whom, when where and how in the sociocultural context (Hudson, 1996, pp. 203-27). It can be said that all the diverse languages and varieties are equal regarding linguistic prestige of rigid application of words and rules. But, the inequality is said to be solely social. 


\section{The Methodology, Data Collection and Analysis}

\subsection{The Aims and Rationales}

The study is aimed at exploring the "Impact of LD on the Social Equality, Equity Pedagogy and Knowledge Construction'. Ecologically, almost all the countries or societies are linguistically diverse, the equal policy and practice of LD and pedagogy maintains and provides reconstruction and construction of knowledge. As rights approach of the de jure and de facto norms of the LD are accepted, admitted, legislated and practiced in Kurdistan Region/ Republic of Iraqi Federal, the reason is to investigate the problems of the LD practice in the de facto norms of LD and social equality at the SU-E social science academic department.

\subsection{Research Questions}

As the methodology of the study is both qualitative and qualitative, the research questions are as follows:

How is the LD context at higher education? Do the LD democratic de jure norms lead to the accepted standards of de facto norms of LD rights? Does the LD practice ensure social equality and equity pedagogy in the academic circumstances? Do LD and social equality provide the required development in learning at the higher education to the standards of knowledge construction that support graduates to enroll in the local, national and international businesses and marketing?

\subsection{Procedures and Participants}

The researcher formally was authorized and permitted by the university officials and teachers to hand out the questionnaire in the classrooms of the related social science departments. The students were respectfully asked to participate or refute the participation. The participants are the senior students of the Humanity Science Departments at Salahaddin University-Erbil (SU-E). They come from diverse residence (rural and urban), class (socio-economic), political, linguistic, religions, gender, education and/or identities backgrounds. The data collected in December 2019. The students i.e. participants come from diverse residence (rural and urban), class (socioeconomic), political, linguistic, religions, gender, education and identities 
backgrounds. The total of $336 / 1600=21 \%$ senior students of all humanity sciences departments participated and filled out the questionnaire.

The majority of the participants' age was between 20-29. Also, 36.9\% of the participants' parents came from the different races or families, $51.5 \%$ came from the same race or family. The male participants were $37.8 \%$ and the female were $58.3 \%$. The place of living of $53.9 \%$ was in city, $20.5 \%$ in suburb, $10.7 \%$ in town, and $13.7 \%$ village. Regarding nationality, Kurdish was $92.3 \%$, Turkumani $2.7 \%$, Syriac $2.4 \%$ Arab $2.4 \%$, other $0.3 \%$. The religion was Muslim 95.5\%, Christian $2.7 \%$, Yezidi $0.3 \%$ others was $0.9 \%$. The main language of Instruction at basic school was Kurdish $92.3 \%$, Arabic $5.1 \%$, English $0.9 \%$, Turkumani $0.3 \%$, and Syriac $1.5 \%$. The main language of Instruction at high school was Kurdish 92.6\%, Arabic 4.5\%, English 1.2\%, Syriac 1.5\%. The main language of Instruction at college was Kurdish 70.8\%, Arabic 6.8\%, English 3.3\%, Syriac 5.7\%, Kurdish and Arabic and English 4.5\%, Kurdish and Arabic 2.1\%, Kurdish and English 6.8\%. The participants financially depended on their family $91.7 \%$, the government $0.9 \%$, other organizations $2.1 \%$, themselves $4.2 \%$. They lived in private houses $82.7 \%$, rented 11.9 , and other $3.0 \%$. The number of the languages that the participants could communicate with was $\mathrm{L} 1=44.6 \%, \mathrm{~L} 2=32.7 \%, \mathrm{~L} 3=: 15.8 \%, \mathrm{~L} 4=$ $4.2 \%$, and $L 5=2.1 \%$. The percent of $27.1 \%$ took private language course and $72.0 \%$ did not take any. The reason why they took language courses was their like $20.8 \%$, need it for university $5.1 \%$, and for a job $8.3 \%$. The participants' first language mark at the $12^{\text {th }}$ grade was $50-59=3.6 \%, 60-69=16.4 \%: 70-79=37.8 \%, 80-89=31.0 \%$, and $90-100=10.1 \%$. Their Arabic language mark at the $12^{\text {th }}$ grade was $50-59=11.6 \%, 60-$ $69=24.1 \%, 70-79=34.2 \%, 80-89=21.4 \%$ and $90-100=7.1 \%$. While, Their English language mark at the $12^{\text {th }}$ grade was $50-59=41.1 \%, 60-69=23.5 \%, 70-79=18.8 \%, 80$ $89=7.7 \%, 90-100=7.1 \%$.

\subsection{Instrument}

The instrument is a questionnaire of the participants' information background and LD. LD is an independent variable and social equality and equity pedagogy as dependent variables, which are a guaranty of language learning and development. Identity is a moderator variable that moderates the relation between LD and equality. 
Other than the information background items, the research items are sixteen likert scale and an item in which it asks the participants' comments or notes about the problem of the study. The items are constructed relying on the basis of the situational background of the students, literature review and theoretical issues of the study on one hand, and, on the other hand, the relevant related resource such as Hudson, (1996), Piller (2016) and O'Neill (2015) and Cheshire and Edwards (1993).

\subsection{Validity and Reliability of the Tool}

The questionnaire is considered both valid and reliable; it has face validity because it had been handed out to many related experts, so that it was modified and reconstructed. Also both outputs of Total Variance Explained (see appendix 1) and Rotated Component Matrix a (see appendix 2) of the factor analysis show that all the items have standard effect in which they proof the factorial validity. Also the following tabulated output shows the degree of reliability:

Table 2: Case Processing Summary of Reliability

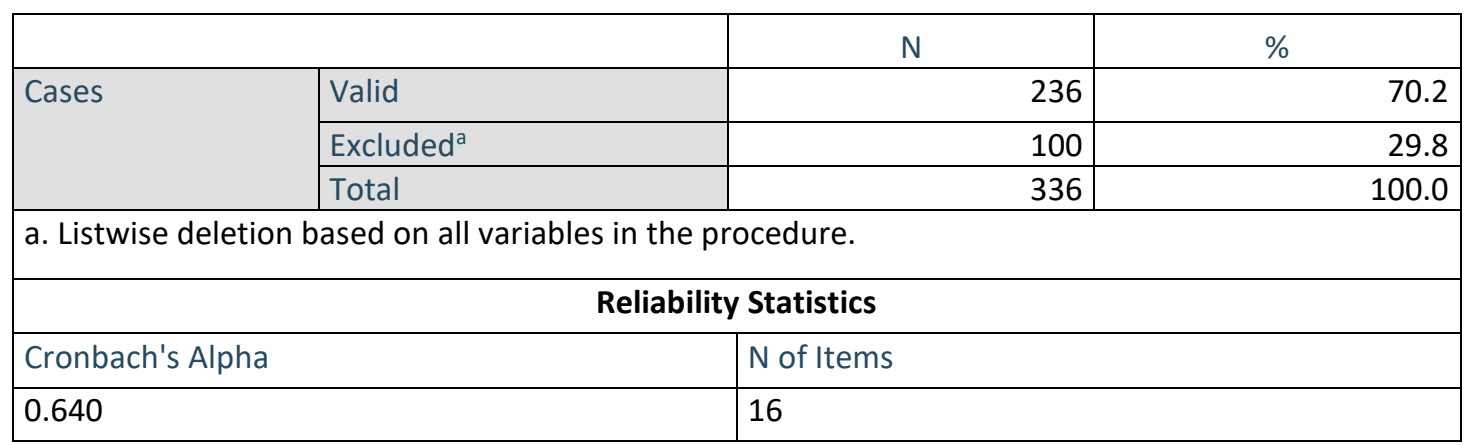

This output of reliability shows that the Cronbch's Alpha is 0.640 , if it is between 0.50 and 0.70 , so, the reliability is quite high and acceptable.

\subsection{Data Analysis and Findings}

The SPSS is adapted for analyzing the collected data. Both frequencies and factor analysis are used for the analysis of the items. That is why the items are grouped into five levels of factors influencing the LD and social and equity pedagogy. 


\subsection{The Factor Analyses of the Items}

Here, the SPSS factor analysis of the items is presented in which it better explains the items of the questionnaire of the students' attitudes.

Table 3: KMO and Bartlett's Test of the Significant

\begin{tabular}{|l|l|l|}
\hline \multicolumn{2}{|l|}{ Kaiser-Meyer-Olkin Measure of Sampling Adequacy. } & .728 \\
\hline \multirow{3}{*}{ Bartlett's Test of Sphericity } & Approx. Chi-Square & 482.091 \\
\cline { 2 - 3 } & Degree of Freedom & Students Number= 120 \\
\cline { 2 - 3 } & Significant & .000 \\
\hline
\end{tabular}

This result shows that the students that have effects on the items are 120 . And, the significant is less than 0,05 or $\% 5$, that is why it is suitable for factor analysis, additionally it shows that the null hypothesis can be rejected. See appendix 1 about Total Variance Explained; in which the output shows that there are five groups of items that there degree is more than $1 ; 1$ or less than 1 . In which four groups of items that are greater than 1 have more impacts. This indicates that these groups of items have the greater impacts, while, the rest of items have lesser impacts. As well as, see appendix 2 of the Rotated Component Matrix and its Graph; in which the tabulated output and graph show that there are four groups of items that have greater effects on the LD, social equality and development positively. The first group is the items: 10 , $13,14,15$ and 16 . The second group is item: 4 only. The third group is items: 1 and 4 . The last group is the items: 2 , and 12 .

\subsection{The Participants' Quantitative Attitudes}

The following are the tabulated outputs of the participants' attitudes sequenced according to factor analysis groups (see appendix 3 of the Frequencies of the Items):

Group One: items 10,13, 14, 15 and 16:

10- In and out of university, there is no cultural discrimination on the basis of LD i.e. people respect the speakers of different languages and varieties equally in action and everyday treatments or conduct:

The general mean (M.) is 3.48, it is positively acknowledged, and the Standard deviation (SD) is 1.158, the attitudes are not too far from each other. While the M. of both Turkumani and Syriac participants is 3.44 and Arabs is 3.0. It indicates that the people of KR culturally, in and out of the university, do not discriminate between 


\section{QALAAI ZANISTSCIENTIFIC JOURNAL \\ A Scientific Quarterly Refereed Journal Issued by Lebanese French University - Erbil, Kurdistan, Iraq \\ Vol. (6), No (1), Winter 2021 \\ ISSN 2518-6566 (Online) - ISSN 2518-6558 (Print)}

individual speakers on the basis of LD, i.e. different more or lesser used languages or varieties are highly respected.

13-Students-learning-centred approach is used i.e. all the students regardless of the language differences and diversities participated in classroom learning, decision making. i.e. curriculum and syllabus design and methods of teaching and learning: The mean is 3.25 , so, it is positively acknowledged, and the SD is 1.142 the attitudes are close enough. It shows that the Students-learning-centred is sometimes implemented. It indicates that the teachers are supposed to help the students to give the student's more classroom teaching and learning preparations in both theoretical and practical sides. In order the students have the ability and chance to manage their learning and development under the supervision of the teachers.

14-Students' identities are accepted and respected, i.e. there is no discrimination on the basis of languages, race, age, gender, economic, social, and tribal backgrounds:

The $M$. is 3.50 , so it is positively acknowledged, and the SD is 1.214 , so, the attitudes are far from each other. It explains that the students' identities whether it is their languages, race, gender or any other related aspects of identity is both accepted and respected. This indicates that the students can freely and without any hesitation develop themselves in the university community and prepare themselves for their future lifelong careers.

\section{5-I am free in thinking such as political ideology:}

The $M$. is 3.63, it is positively acknowledged, and the SD is 1.261 , the attitudes are rather far from each other. It shows that the majority of participants acknowledge that free thinking and self-expressing are democratically realized. This provides the students as academicians sociopolitical equality that provides them freedom of acts and praxis.

16-The stakeholders (decision makers, teachers and students) of educational process are cooperative, understanding each other, accept and respect each other in the classroom and institutional settings:

The M. is 3.29, it is again positively acknowledged, and the SD is 1.073 , so the attitudes are close enough. The result explains that the participants or stakeholders of education at university in general are cooperative enough, so that they understand what they want and need for the purposes of higher education and development. 


\section{QALAAI ZANISTSCIENTIFIC JOURNAL \\ A Scientific Quarterly Refereed Journal Issued by Lebanese French University - Erbil, Kurdistan, Iraq \\ Vol. (6), No (1), Winter 2021 \\ ISSN 2518-6566 (Online) - ISSN 2518-6558 (Print)}

\section{Group Two: Item 4 only:}

4-LD i.e. different languages and varieties or dialects are accepted and respected in Kurdistan including my first language. i.e. I studied my L1 at school:

The $M$. is 4.15, it is highly positive acknowledgement, and the SD is 1.174 , so the attitudes are close enough. The great majority of the participants accept and respect the LD in Kurdistan Region. This provides the students social equality and linguistic security for the existent communities in the region. This indicates that the individual students have chance to learn and develop the first language which sets in the minds of the speakers. On this base, they can develop the required additional languages.

\section{Group Three: Items 1 and 7:}

\section{1-I am proud of my mother tongue or first language:}

The $M$. is 4.56, it is highly positive acknowledgment, and the SD is 1.026, the attitudes are close to each other. It shows that the majority of the students are loyal to their first language and they love them as their linguistic and national identity. This shows that the first language of the students as the language of understanding, the foundation of the L1 supports smooth acquisition of the additional languages, it is the language of seeing the world, and identity should be respected and more developed either as a subject or as a medium of instruction.

7- At university and in real life, other than academic languages such as Kurdish, Arabic, and English, we need to learn minority or less used languages such as Turkumani and Syriac for everyday communication and knowledge:

The $M$. is 3.2, so it is positively recognized, and the SD is 1.428 , therefore the attitudes are far from each other. Although, the majority of the participants are Kurdish but this output shows that the majority of the participants feel that they need to learn Turkumani and Syriac for everyday communication and interaction. This indicates that the universities have a duty to open the minority language courses as subjects for those who are interested to learn.

\section{Group Four: Items Two and Twelve:}

\section{2-I read in first language (L1) only:}

The $M$. is 3.63 , it is positively acknowledged, and the SD is 1.353 , the attitudes are far from each other. Here, reading whether intensive or extensive is the best way for 


\section{QALAAI ZANISTSCIENTIFIC JOURNAL \\ A Scientific Quarterly Refereed Journal Issued by Lebanese French University - Erbil, Kurdistan, Iraq \\ Vol. (6), No (1), Winter 2021 \\ ISSN 2518-6566 (Online) - ISSN 2518-6558 (Print)}

learning and developing the first and additional languages. It shows that the majority of the participants read resources by their own language. However, the resources by the academic languages are available in both physical and digital libraries. Still, this indicates that the teachers are supposed to give the students tasks in different required academic languages to help oblige the students use the languages.

12-I can translate from my first language to other academic languages such as English: The M. is 2.55 , it is negatively acknowledged, and the SD is 1.302 , so the attitudes are far from each other. As translation is regarded as a language skill, it is important for the university students be proficient enough in translating texts of their specializations. Researching is the dominant technique of studying at university, so, not only teachers but also students need to have this translation skill because the academic languages are diverse. This output indicates that the students lack the translation skill as a way of gaining knowledge.

Group Five: the least effective factors: $3,5,6,8,9$, and 11:

3-Studetns have equal opportunities in studying, participation and development:

The $M$. is 2.89 , so it is negatively acknowledged, and the SD is 1.365 , the attitudes are far from each other. It shows that more participants feel that the students do not have chance in studying, participation and development. It indicates that there is a kind of social and pedagogical inequality in the university classroom settings. In this case, teachers and decision makers are supposed to find out about the reasons of what are the things that make the students feel inequality.

5-LD i.e. different languages and varieties or dialects are accepted and respected in Iraq including my first language i.e. People study their L1 at school:

The $M$. is 3.65 , it is positively acknowledged and the SD is 1.322 , so the attitudes are far from each other. This output shows that the participants admit that LD is also accepted and respected. This has positive indication on LD regarding learning and development; because the students feel free while learning depending on what they are (linguistically) not should be imperiously.

6-I think that LD is not a problem. It is an advantage, a resource of power, i.e. all the different language speakers are powerful together and can develop learning and experience:

The $M$. is 4.07 , it is highly positively acknowledged, and the SD is 1.989 , so the attitudes are close enough. The output shows that the great majority of the 


\section{QALAAI ZANISTSCIENTIFIC JOURNAL \\ A Scientific Quarterly Refereed Journal Issued by Lebanese French University - Erbil, Kurdistan, Iraq \\ Vol. (6), No (1), Winter 2021 \\ ISSN 2518-6566 (Online) - ISSN 2518-6558 (Print)}

participants thinks and believes that LD is power not weakness or problem. This indicates that the communities positively accept and respect the LD, they believe in equity and coexistence. In which, this cultural ideology, philosophy or viewpoint leads to real social coexistence, in turn, it is supposed to lead to more knowledge reconstruction, construction and creative development.

\section{8-Both theoretical and practical knowledge are taught and learnt together, i.e. we practice what language or the knowledge we learn; that is why I am very good in knowledge and languages.}

The $M$. is 3.23 , it is positively acknowledged, and the SD is 2.604 , so the attitudes are too far from each other. Although the participants positively acknowledged that the balance between theory and practice is kept but the standard deviation shows that the participants are clearly far from their admittance. This indicates that the balance between theoretical and practical knowledge has problems in the study of humanity sciences departments.

9-The means of researching (physical and digital libraries) are found and are in a good quality.

The $M$. is 3.08 , it is positively acknowledged, and the SD is 1.216 , so the attitudes are not very far from each other. Researching as a technique of learning and teaching is crucial and significant at higher education. Because it is the only best way that opens the doors of knowledge and information for both the students and the teachers as researchers. The mean here shows that the participants not strongly positively acknowledge the researching techniques. The university can again provide course of researching, provide modules in the curricula. And the teachers are required to give the students the tasks that can be conducted independently via library research, so that, it can enhance the student-researcher characteristics.

\section{1-Whenever needed, the university provides me courses of my first language and other academic languages such as Arabic and English.}

The $M$. is 2.10 , it is negatively acknowledged, and the SD is 1.312 , so the attitudes are close enough. Though, the university students have loyalty to their first language, they accept LD, the academic languages are diverse typologically, the university is supposed to provide the students with the academic and non-academic language courses for better, more and easier knowledge construction. 
Vol. (6), No (1), Winter 2021

ISSN 2518-6566 (Online) - ISSN 2518-6558 (Print)

\subsection{The Participant Qualitative Attitudes}

\section{7- The Students' Comments}

The following are some comments of the students' qualitative attitudes:

-"English language is needed for studying during the four years of study in our department".

-"Teachers only want to finish the contents, they do not focus on our learning".

-"Arabic and English languages are neglected in our department".

-"LD should be more taken into consideration".

-"The curriculum does not help learn the required languages, the students do not understand the contents properly, there should be a notable curriculum revision and development".

-"LD implementation shows that there are diverse nations and religions, it should be developed, I prefer the balance between Kurdish, Arabic and English in the Curriculum".

-"I hope that the university provides adequate free language courses for students, theoretical knowledge is useless without practical knowledge, the ability to speak with the required languages is very important".

-"I think the problem is not with the LD or the contents of the curricula, it is with teaching".

-"our curriculum is in Arabic, we study it in Kurdish, and take the test in Arabic".

-"I hope language would not be a must in jobs"

-"We study and focus on Kurdish language in the curriculum, but it does not work when seeking jobs, we need to know other languages as well".

-"English language should be balanced with Kurdish language at university".

-"Kurdish is useful with other academic languages only". 
Vol. (6), No (1), Winter 2021

ISSN 2518-6566 (Online) - ISSN 2518-6558 (Print)

-"Our native language (Kurdish) should be used, but students need courses to learn Arabic and English languages so that they can use them proficiently and have job opportunities".

-"Kurdish language is going to distinct, we need to take careful care of it, it is our honor".

-"Arabic and English languages are taught in Kurdish in the basic and preparatory schools, teachers do not use them, when we enroll at university the Kurdish language is not of that important because the resources are not in Kurdish. The universities instructors are also speak in Kurdish only. I hope this study will not only be conducted for personal purposes, the results should be taken in to consideration by the authorities".

-"I hope the results of this work will be really implemented".

-"The system of the study at Salahaddin University is not according to the needs".

-"As a student, although I tried hard to learn other languages such as English language that can help find a job, but I could not, the curriculum is not helpful in this regard".

-"Other languages should be really learnt not only as a passage for passing".

-"There should be an optional module for learning international languages, so that the students who like or need it learn it".

-"We did not see any difference between the college and school systems".

-"Every English language teacher uses an accent, some use UK, some use USA, and others use Australian. We are confused".

-"The means of instruction is English language in our department but we still cannot speak in English, the public university students have language problems".

-"I hope Kurdish language will not be neglected, it is our identity"

-"Writing or rewriting lecture have to be banned".

-"One problem is that the written presentation is in Arabic or in English while the spoken explanation is in Kurdish, we do not understand in this way". 
Vol. (6), No (1), Winter 2021

ISSN 2518-6566 (Online) - ISSN 2518-6558 (Print)

-"I hope to study all the modules practically".

-" I prefer the university opens language courses especially English language courses free or with low price for the student, also, I prefer a day of using English language used in debates between the students and the teachers".

-"One great problem is translation, the contents of the modules are meaninglessly translated from Arabic or English to Kurdish in which the learning is not deep".

-"linguistics diversity should be implemented at the higher education, we need to balance between Kurdish, Arabic and English".

-"I hope the Arabic language be equally studied".

-"I did not face any problem related to LD policy".

-"The psychological and social problems made us not to make developments and less make use of the modern technologies".

-"There should be at least one native English language teacher".

-'These students' rights are not found, the students neither know Arabic nor English".

\subsection{Findings}

It has been found that the policy and practice of the LD have greater role in the social equality at the level of the SUE, in which the results can be generalized for reconstructing and developing the higher education methodology, curricula, evaluation and administration. But the de jure or legislated laws to the policy of LD and the de facto norms in the classroom and institutional settings need to be more developed pragmatically so that it ensures both deductive and inductive approaches, the balance between theoretical and practical, the assessment and measurement (evaluation approach) of teaching, learning and LD implementation to confirm equity pedagogy and participation and development opportunities.

\subsection{Results}

The following graph shows the results of the means and standard deviation of the items of the study. 


\section{QALAAI ZANISTSCIENTIFIC JOURNAL}

A Scientific Quarterly Refereed Journal Issued by Lebanese French University - Erbil, Kurdistan, Iraq

Vol. (6), No (1), Winter 2021

ISSN 2518-6566 (Online) - ISSN 2518-6558 (Print)

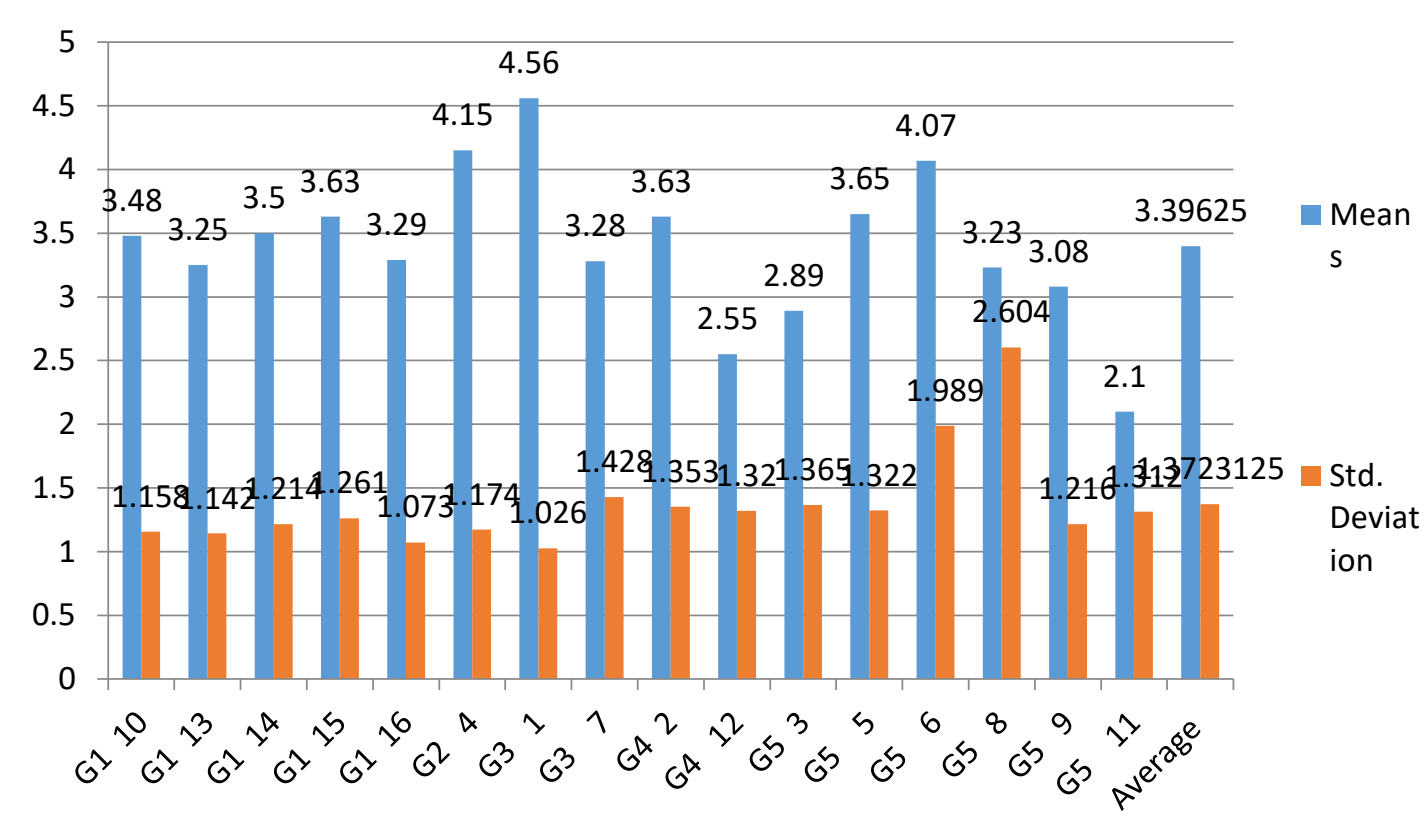

The blue columns are the results of the means divided into five groups of factorial analysis i.e. the items that have greater impact. Also, there are only three negative item acknowledgements they are item 12 of group 4; and items 3 and 11 of group 5 . The red columns are Std.D. they identify the participants close or far (hesitations) attitudes, the greater Std.D distance between the participants attitudes are items 6 and 8 of group 5. The following are some strong and weak points and recommendations by the participants:

\subsubsection{Strengths}

Generally and relationally, LD is socioculturally and sociolinguistically accepted, respected, and developed via the oral and written communication in and out of the institutional settings. All the minority languages and varieties are respected by the Kurdish majority speakers and requested to be learnt and used in the needed contexts, so democratic LD policy and practice is respected, accepted and can easily be implemented as it is. Additionally, it is legislated as the de jure norms are sometimes implemented as the de facto norm. So, LD is regarded as an advantage not as a problem. The student-learning-centered is implemented in the teaching and learning processes, so that the teachers share their teaching with the students i.e. the 
students conduct much of the classroom interactions and actions. The students' identities are respected, so that, they enjoy their personal, social, cultural and linguistic identities, in which, it provides them self-determination and conceptualization. Both cooperative and collaborative learning techniques are implemented but not well systematic methodically. The first language is proudly respected as an identity and language of understanding and initiation to lifelong knowledge construction and careers. Furthermore, theoretical and practical knowledge are slightly balanced.

\subsubsection{Weaknesses}

Using only Kurdish language as the first language of the majority students at higher education does not provide the university students academic professional proficiencies, on one hand, the resources are not only in Kurdish language but also in Arabic and English languages, and on the other hand, the local, national and international contexts are linguistically and culturally diverse. Linguistically diverse students are not provided with additional language courses, in which it influences the loss of language use as both oral and written means of communication and knowledge gaining. Knowledge reconstruction and construction is not according to the university academic standards because of the lack of linguistic and academic professional proficiencies. Deficiency in translation skill that affects students' ability to gain knowledge from different linguistic and content resources of the literatures is an institutional issue, so that the students as researchers might only have the ability to gain translated of second hand knowledge from the original literature resources. Unequal opportunities demotivate, destruct the students' developments and creative construction. The least balance between theoretical and practical knowledge, and, assessment and measurement as two poles of evaluation in general are some negative outcomes of the results.

\subsubsection{Proposed Solutions}

The three academic languages should be used not as subjects only but as media of education and instruction, students need to be provided with the academic language proficiency skills courses. Theoretical knowledge without practical knowledge is useless because it does not lead to learning and reaching higher levels of cognition, psychomotor, affective, and sociocultural requirements. The problem is that not only Kurdish and Arabic have varieties but there are Englishes also, so the curriculum design and implementation should be verified with the dominant academic 
languages, for instance choosing between British and American dialects because some teachers use British while others use American dialects that makes problems for the students understanding. The majority of the subjects that are studied in Kurdish are translated from Arabic and English and it loses meaning, it becomes a kind of second-hand slightly meaningless knowledge, that is why, a committee of translators need to review the translated contents and translation could be used as a technique in each scientific department accordingly. Evaluation weather formative or summative should depend on both tests as measurement technique and portfolios as assessment techniques in order to ensure the balance between both theoretical and practical knowledge re/construction.

\section{Conclusions, Recommendation and References}

\subsection{Conclusions}

It has been found that the LD has least de jure norms problems i.e. LD democratic policy and planning is accepted and respected by the government and the people, it is socioculturally recognized.

However, it has been concluded that the LD implementation at the HSs is mainly monolingual; it is not trilingual as it should be according to the LD academic ecology, i.e. the balance between Kurdish as national language, Arabic as a supernational language and English as an international academic language is not kept. So, both language objectives and content objectives are not achieved enough. That is why, the graduates are both theatrically and practically not well-prepared.

The limitations of this study derive from the fact that the method of data collection only relies on the attitudes not aptitudes i.e. participants perspectives and not test. There are no tests of the participants' language and content professional proficiency that could provide accurate generalizable results.

The findings in the study indicate a need for further research to explore whether the authorities constantly follow up the students' and other stakeholder feedback into consideration or not properly? And how?

It is concluded that the LD policy or de jure norms do not have problems. The problems are that Kurdish language is mainly used in the HSs communications and curricula. There are translation problems, so that translated contents are not 
understandable. There are problems of practical knowledge. Equal opportunities are also not provided.

The study is constructive and advantageous for all the teachers, decision makers, and curriculum developers of the humanity sciences departments. The study can be applied in the implementation of the approaches to the LD to the students' social equality, justice and equity pedagogy. As well as, it can be applied in classroom problems of learning and developments in which it is the key idea and objectives of the education at the humanity sciences departments for the preparation of graduates for the critical competition of marketing and businesses that can help the individual students to actively and successfully enroll in their future lifelong careers.

It is better for the university to take careful care of the students' LD and social equality, justice and equity pedagogy to ensure the required dynamic knowledge reconstruction, construction and development.

\subsection{Recommendations}

The following are some determined recommendations:

It is better for the university to provide the teachers and the students with information about the policy and practice of LD in the curricula.

It is better for the university to start free courses of Kurdish (especially written), Turkumani, Arabic and Syriac courses for those students who are in need or interested in it or like it.

It is better for the university to open the department of translation between Kurdish, Arabic and Kurdish languages. Also, every academic course book or logbook should be evaluated by a committee of translators (the translation of the resources between Kurdish, Arabic and English) and scientific academicians in order to ensure the original and standardized knowledge or science.

It is better for the university to ask the students' and the teachers' feedback yearly and progress the regulations, interactions, theoretical and practical knowledge gaining. So that, the university could decrease the level of social inequality and inequity pedagogy to its least level, because, it is the heart of the LD policy, practice and curriculum implementation to the developments. 


\section{QALAAI ZANISTSCIENTIFIC JOURNAL \\ A Scientific Quarterly Refereed Journal Issued by Lebanese French University - Erbil, Kurdistan, Iraq \\ Vol. (6), No (1), Winter 2021 \\ ISSN 2518-6566 (Online) - ISSN 2518-6558 (Print)}

\section{REFERENCES}

AITCHESON, JEAN. 1999. Teach Yourself Linguistics. London, Hodders Headlins.

BELL, ROGER T.. 1976. Sociolinguistics - goals, approaches and problems. London: Batsford. Blommaert, Jan. 2013. Language and the study of diversity. In: Handbook of Diversity Studies (Routledge, Steve Vertovec, ed. 2014). Tilburg Papers in Cultural Studies 74. [pdf] available at https://www.tilburguniversity.edu/upload/2648cf26-31f2-413883d3-3176cabc28b0 TPCS 74 Blommaert.pdf (accessed 10 November 2017).

Cheshire, Jenny and Edwards, Viv. 1993. Sociolinguistics in the classroom: exploring LD. In:

Real English: the grammar of English dialects in the British Isles. Longman, Editors: James Milroy, Lesley Milroy. Taylor \& Francis. Routledge (2014). [pdf] available at:https://www.researchgate.net/publication/274364652 Sociolinguistics in the c lassroom exploring linguistic diversity Accessed in 11 January 2018.

COMMINS, NANCY L. \& MIRAMONTES, OFELIA B. 2005. LD and Teaching. Lawrence Erlbaum Associates. New Jersey.

CRUZ, BARBARA C. ELLERBROCK, CHERYL R. VASQUEZ, ANETE. \& HOWES, ELAINE V. 2014. Talking Diversity with Teachers and Teacher Educators: Exercises and Critical Conversations Across the Curriculum. Ed. Teachers College, Colombia University. New York.

CRYSTAL, DAVID. 2011. Internet Linguistics. Routledge.

-------, DAVID. 2015. Towards a Philosophy of LD. [pdf] available at: http://www.davidcrystal.com/?fileid=-4132 (accessed 16 May 2019).

GOSLING, DAVID. Supporting Student. In: Fry, Heather. Ketteridge, Steve and Marshall, Stephanie. 2003. A handbook for Teaching \& Learning in Higher Education. Ed2. Kogan Page Limited.

Halliday, M. A. K. Ed. by Webster, Jonathan J. 2007. Language and Education. The Collected Works of M. A. K. Halliday. London \& New York. Biddies Ltd., King's Lynn, Norfolk.

HUDSON, R.A.1996.Sociolinguistics. Ed, 2. Cambridge University Press.

HUSZTI, ILONA. 2013. Glossary on Language Teaching and Learning. Beregszász. [pdf] available at libgen.com.

LIM, CHIH-ING. 2006. Cultural and LD in Early Childhood Teacher Preparation: The Impact of Contextual Characteristics on Coursework and Practica. University of North Carolina at Chapel Hill. [pdf] available at https://cdr.lib.unc.edu/indexablecontent/uuid:2c87780c-78cc-4806-b7e11bbecbe9109c [accesses in 5 March 2018].

International Covenant on Civil and Political Rights. 1966. [Pdf] available at https://www.ohchr.org/Documents/Professionallnterest/ccpr.pdf $\quad$ (accessed 2 November 2019). 


\section{QALAAI ZANISTSCIENTIFIC JOURNAL \\ A Scientific Quarterly Refereed Journal Issued by Lebanese French University - Erbil, Kurdistan, Iraq \\ Vol. (6), No (1), Winter 2021 \\ ISSN 2518-6566 (Online) - ISSN 2518-6558 (Print)}

JANSSENS, MADDY AND STEYAERT, CHRIS. 2003. Theories of Diversity within Organisation Studies: Debates and Future Trajectories. [pdf] available at: https://core.ac.uk/download/pdf/6264654.pdf Accessed [3 November 2017].

MURRAY, DENISE E. AND CHRISTISON, MARYANN. 2011.What English Language Teachers Need to Know? Volume I: Understanding Learning . Routledge. Taylor \& Francis.

NASIR, NA'ILAH SUAD . Rowley, Stephanie J. . and Perez, William . 2016. Cultural, Racial/Ethnic, and LinguisticDiversity and Identity. https://www.researchgate.net/publication/282709140 Cultural racialethnic and I inguistic diversity and identity .9/10/2019.

NETTLE, DAANIEL. 2002. LD. New York, Oxford University Press.

NEVEZ, ADAM LE. 2006. Language Diversity and Linguistic Identity in Brittany: a Critical Analysis of the Changing Practice in Britton. Thesis. Available at: https://opus.lib.uts.edu.au/bitstream/2100/312/2/02WholeThesis.pdf (Accessed in 12 May 2018).

O'NEILL, G. (2015). Curriculum Design in Higher Education: Theory to Practice. Dublin: UCD Teaching \& Learning. ISBN 9781905254989 http://www.ucd.ie/t4cms/UCDTLP0068 . pdf . Also available from UCD Research repository at:

http://researchrepository.ucd.ie/handle/10197/7137

PILLER, INGRID. 2016. LD and Social Justice; An Introduction to Applied Sociolinguistics. Oxford University press.

Pritchard, Alan. 2007. Effective Teaching with Internet Technologies Pedagogy and Practice. Paul Chapman. London.

RICHARDS, J.C. AND SCHMIDT R. WITH KENDRICKS, H. AND U KIM, Y., 2002. Longman Dictionary of Language Teaching and Applied Linguistics. ed3rd. London, New York: Pearson Education Limited.

JHA, MADAN MOHAN. Barriers to student access and Success: Is inclusive education an answer? In : Verma, Gajendra K. Bagley, Christopher R. and Jha, Madan Mohan. 2007 International Perspectives on Educational Diversity and Inclusion Studies from America, Europe and India. Routledge.

LAZARD, GILBERT. What are we Typologists Doing?. in: Frajzyngier, Zygmunt. Hodges Adam

And Rood, David S. ed . 2005 . LD and Language Theories. John Benjamins B.V.ch 1. SAMPSON, GEOFFREY. 1980. Schools of linguistics. Stanford University Press.

Universal Declaration of Human Rights. 2015. United Nations [PDF] available at :

https://www.un.org/en/udhrbook/pdf/udhr booklet en web.pdf (Accessed in November 2019). 


\section{QALAAI ZANISTSCIENTIFIC JOURNAL}

A Scientific Quarterly Refereed Journal Issued by Lebanese French University - Erbil, Kurdistan, Iraq

Vol. (6), No (1), Winter 2021

ISSN 2518-6566 (Online) - ISSN 2518-6558 (Print)

\subsection{Appendices}

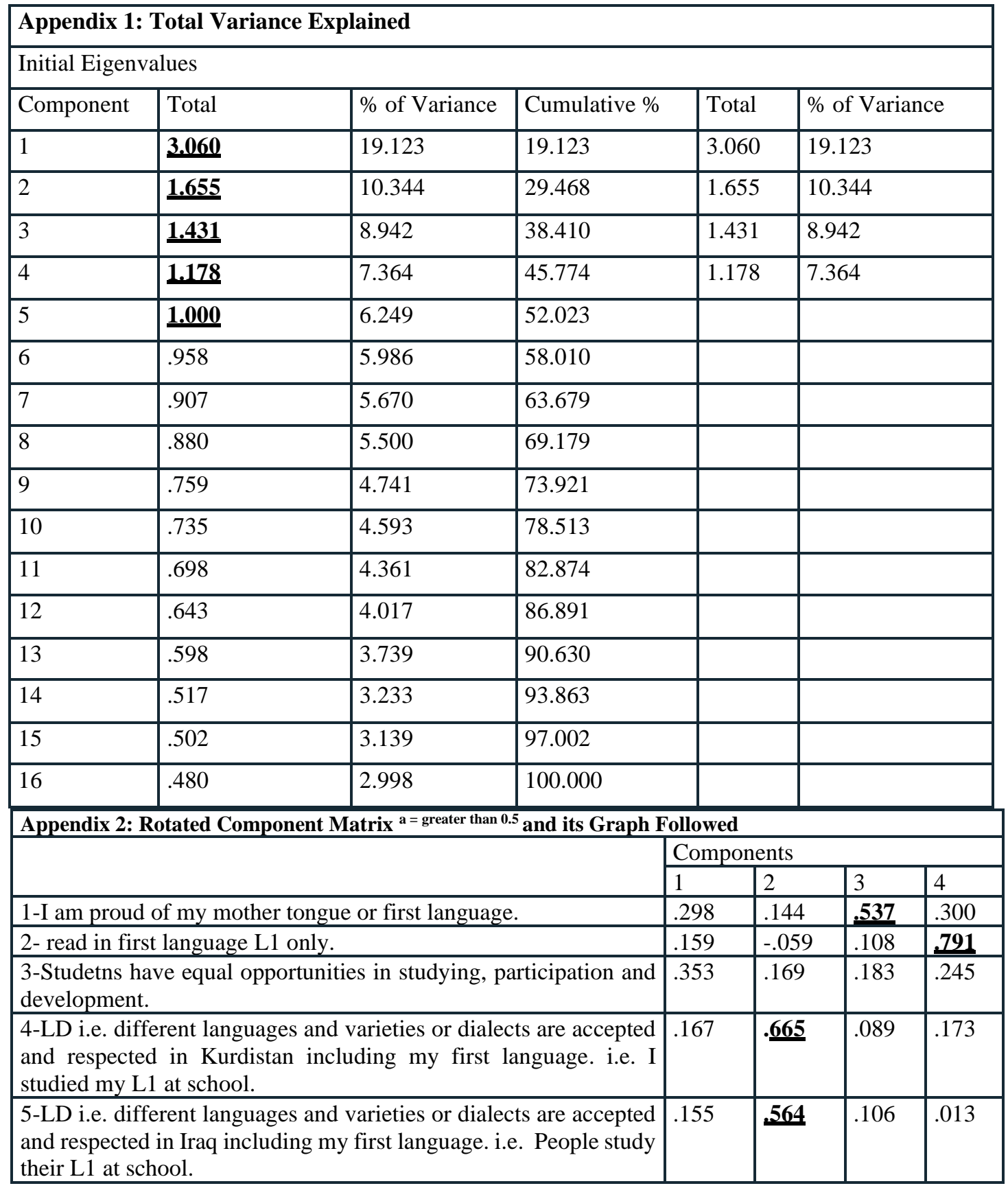




\section{QALAAI ZANISTSCIENTIFIC JOURNAL}

A Scientific Quarterly Refereed Journal Issued by Lebanese French University - Erbil, Kurdistan, Iraq

Vol. (6), No (1), Winter 2021

ISSN 2518-6566 (Online) - ISSN 2518-6558 (Print)

\begin{tabular}{|c|c|c|c|c|}
\hline $\begin{array}{l}\text { 6-I think that LD is not a problem. It is an advantage, a resource of } \\
\text { power, i.e. all the different language speakers are powerful together } \\
\text { and can develop learning and experience. }\end{array}$ & -.088 & .404 & .487 & -.204 \\
\hline $\begin{array}{l}\text { 7-At university and in real life, other than academic languages such } \\
\text { as Kurdish, Arabic, and English, we need to learn minority or less } \\
\text { used languages such as Turkumani and Syriac for everyday } \\
\text { communication and knowledge. }\end{array}$ & .037 & .030 &.$\underline{716}$ & -.073 \\
\hline $\begin{array}{l}\text { 8-Both theoretical and practical knowledge are taught and learnt } \\
\text { together, i.e. we practice what language or the knowledge we learn; } \\
\text { that is why I am very good in knowledge and languages. }\end{array}$ & .079 & -.441 & .434 & .142 \\
\hline $\begin{array}{l}\text { 9-The means of researching (physical and digital libraries) are } \\
\text { found and are in a good quality. }\end{array}$ & .564 & -.233 & .004 & .057 \\
\hline $\begin{array}{l}\text { 10- In and out of university, There is no cultural discrimination on } \\
\text { the basis of LD i.e. people respect the speakers of different } \\
\text { languages and varieties equally in action and everyday treatments } \\
\text { or conduct. }\end{array}$ &. $\mathbf{5 3 0}$ & .338 & .109 & -.074 \\
\hline $\begin{array}{l}\text { 11-Whenever needed, the university provides me courses of my } \\
\text { first language and other academic languages such as Arabic and } \\
\text { English. }\end{array}$ & .475 & -.447 & .336 & -.236 \\
\hline $\begin{array}{l}\text { 12-I can translate from my first language to other academic } \\
\text { languages such as English. }\end{array}$ & .273 & -.093 & .216 & -.689 \\
\hline $\begin{array}{l}\text { 13-Students-learning-centred approach is used i.e. all the students } \\
\text { regardless of the language differences and diversities participated } \\
\text { in classroom learning, decision making. i.e. curriculum and } \\
\text { syllabus design and methods of teaching and learning. }\end{array}$ &.$\underline{566}$ & .079 & .150 & -.052 \\
\hline $\begin{array}{l}\text { 14-Students' identities are accepted and respected. i.e. there is no } \\
\text { discrimination on the basis of languages, race, age, gender, } \\
\text { economic, social and tribal backgrounds. }\end{array}$ &.$\underline{.576}$ & .392 & .003 & -.092 \\
\hline $15-\mathrm{I}$ am free in thinking such as political ideology. & .512 & .132 & .193 & .290 \\
\hline $\begin{array}{l}\text { 16-The stakeholders (decision makers, teachers and students) of } \\
\text { educational process are cooperative, understanding each other, } \\
\text { accept and respect each other in the classroom and institutional } \\
\text { settings. }\end{array}$ &.$\underline{661}$ & .054 & -.099 & .013 \\
\hline \multicolumn{5}{|l|}{$\begin{array}{l}\text { Extraction Method: Principal Component Analysis. } \\
\text { Rotation Method: Varimax with Kaiser Normalization. }{ }^{\mathrm{a}}\end{array}$} \\
\hline a. Rotation converged in 9 iterations. & & & & \\
\hline
\end{tabular}




\begin{tabular}{|c|c|c|c|c|c|c|c|}
\hline Appendix 3: The Frequencies of the Items & & & & & & & \\
\hline Items & 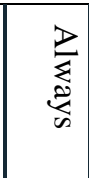 & 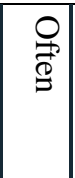 & 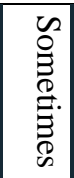 & $\begin{array}{l}\overrightarrow{0} \\
\stackrel{0}{0} \\
\stackrel{0}{<}\end{array}$ & 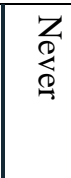 & 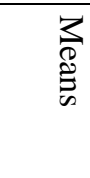 & 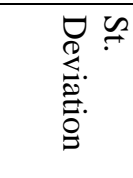 \\
\hline 1-I am proud of my mother tongue or first language. & 259 & 38 & 10 & 7 & 17 & 4.56 & 1.026 \\
\hline 2-Iead in first language L1 only. & 119 & 70 & 75 & 25 & 39 & 3.63 & 1.353 \\
\hline $\begin{array}{l}\text { 3-Studetns have equal opportunities in studying, } \\
\text { participation and development. }\end{array}$ & 59 & 37 & 92 & 64 & 63 & 2.89 & 1.365 \\
\hline $\begin{array}{l}\text { 4-LD i.e. different languages and varieties or dialects are } \\
\text { accepted and respected in Kurdistan including my first } \\
\text { language. i.e. I studied my L1 at school. }\end{array}$ & 182 & 69 & 42 & 19 & 18 & 4.15 & 1.174 \\
\hline $\begin{array}{l}\text { 5-LD i.e. different languages and varieties or dialects are } \\
\text { accepted and respected in Iraq including my first language. } \\
\text { i.e. People study their L1 at school. }\end{array}$ & 125 & 66 & 77 & 36 & 31 & 3.65 & 1.322 \\
\hline $\begin{array}{l}\text { 6-I think that LD is not a problem. It is an advantage, a } \\
\text { resource of power, i.e. all the different language speakers are } \\
\text { powerful together and can develop learning and experience. }\end{array}$ & 149 & 78 & 68 & 28 & 10 & 4.07 & 1.989 \\
\hline $\begin{array}{l}\text { 7-At university and in real life, other than academic } \\
\text { languages such as Kurdish, Arabic, and English, we need to } \\
\text { learn minority or less used languages such as Turkumani and } \\
\text { Syriac for everyday communication and knowledge. }\end{array}$ & 91 & 66 & 78 & 39 & 58 & 3.28 & 1.428 \\
\hline $\begin{array}{l}\text { 8-Both theoretical and practical knowledge are taught and } \\
\text { learnt together, i.e. we practice what language or the } \\
\text { knowledge we learn; that is why I am very good in } \\
\text { knowledge and languages. }\end{array}$ & 47 & 70 & $\begin{array}{l}10 \\
9\end{array}$ & 66 & 33 & 3.23 & 2.604 \\
\hline $\begin{array}{l}\text { 9-The means of researching (physical and digital libraries) } \\
\text { are found and are in a good quality. }\end{array}$ & 51 & 71 & $\begin{array}{ll}10 \\
8\end{array}$ & 67 & 39 & 3.08 & 1.216 \\
\hline $\begin{array}{l}\text { 10- In and out of university, There is no cultural } \\
\text { discrimination on the basis of LD i.e. people respect the } \\
\text { speakers of different languages and varieties equally in } \\
\text { action and everyday treatments or conduct. }\end{array}$ & 83 & 78 & $\begin{array}{l}10 \\
4\end{array}$ & 53 & 15 & 3.48 & 1.158 \\
\hline $\begin{array}{l}\text { 11-Whenever needed, the university provides me courses of } \\
\text { my first language and other academic languages such as } \\
\text { Arabic and English. }\end{array}$ & 25 & 35 & 49 & 63 & $\begin{array}{l}16 \\
1\end{array}$ & 2.10 & 1.312 \\
\hline $\begin{array}{l}\text { 12-I can translate from my first language to other academic } \\
\text { languages such as English. }\end{array}$ & 34 & 38 & 82 & 74 & 87 & 2.55 & 1.320 \\
\hline
\end{tabular}




\section{QALAAI ZANISTSCIENTIFIC JOURNAL}

A Scientific Quarterly Refereed Journal Issued by Lebanese French University - Erbil, Kurdistan, Iraq

Vol. (6), No (1), Winter 2021

ISSN 2518-6566 (Online) - ISSN 2518-6558 (Print)

13-Students-learning-centred approach is used i.e. all the students regardless of the language differences and diversities participated in classroom learning, decision making. i.e. curriculum and syllabus design and methods of teaching and learning.

14-Students' identities are accepted and respected. i.e. there is no discrimination on the basis of languages, race, age, gender, economic, social and tribal backgrounds.

15 -I am free in thinking such as political ideology.

16-The stakeholders (decision makers, teachers and students) of educational process are cooperative, understanding each other, accept and respect each other in the classroom and institutional settings.

\begin{tabular}{|l|l|l|l|l|l|l|}
\hline 53 & 80 & $\begin{array}{l}11 \\
8\end{array}$ & 52 & 26 & 3.25 & 1.142 \\
\hline 90 & 79 & 89 & 56 & 19 & 3.50 & 1.214 \\
\hline 98 & 73 & 77 & 28 & 26 & 3.63 & 1.261 \\
\hline 46 & 94 & $\begin{array}{l}11 \\
8\end{array}$ & 52 & 19 & 3.29 & 1.073 \\
\hline
\end{tabular}




\section{QALAAI ZANISTSCIENTIFIC JOURNAL}

A Scientific Quarterly Refereed Journal Issued by Lebanese French University - Erbil, Kurdistan, Iraq

Vol. (6), No (1), Winter 2021

ISSN 2518-6566 (Online) - ISSN 2518-6558 (Print)

\section{كاريكهرى فرهزمانهوانى له سهر دادى وانهوتنهوه و بنياتنان}

فره زمانهوانى واته ههمهجهشنهي. لِّرهدا، واته كوّزمانهوانى ئهكاديمى و نائهكاديمى قوتابيان. ههروهها دادى كوّمهلاّيهتى و دادوهرى له وانه وتنهوه سهلمينهارى ههلى يهكسانن و فهراهه مهيّنهرى يِيشكهوتنى بهردهوام دهكهن بهرهو بهدهستهيّنانى زانست و زانيارى و بنياتنان داهيّنه رانه. لهروى ئيّكوّلوَجيهوه له دهرهوه و له ناوهوهى دامودمزكا يهروهردهيى و زانسته مروّايهتيهكان زينكه زمانهوانيهكه فره زمانهوانى و كهلتوريه. كيّشكه ئهوهيه يِيشبينى دهكرى كه قوتايانى زانسته مروّقايهتيهكان لهروى زمانهوانى و زانست زانيارى تيوّرى و كردارى كارامهبن، بهلّام راميارى و يلان و و جيّبهجيّكردن يارمهتيدهرى قوتابيان نين كه بكهنه ئاستى زمانهوانى زانستى بهرز بهكويّرىى ستانداردهانى خويَندنى بالَا.

يرسيارهكان بهم شيّوهيهن: نايا فرهزمانهوانى به شيّوهيهكى ريّك جيّبهجن دهكري؟ نايا فره زمانهوانى بوّته هوّى بنياتنانى زانست و زانيارى لاى قوتابيان؟ يرِّوسهى دادى كوّمهلّايهتى وانهوتنهوه جِوّنه له لايهنى وانهوتنهوه و فيّربوون و كاركِيِّى يوّلى؟ يِيشبينى ئهوهيه كه فرهزمانهوانى به باشى جيّبه جى نهكراوه وهكو خوّى و بهكوّيَرهى يِيّويستيهكانى قوتابيان. كهواته لهوانهيه دهرجوهكان كارامه نهبن لهروى زمانهوانى و ئهكاديمى كه بتوانن كاربكهن له ئاستى ناوجهيى و نيشتمانى نيّونهتهوهيى. ئامانج دوّزينهوهى كيّشهانى فره كوّزمانهوانيه له وانه وتنهوه و فيّربوون و يِيّشكهوتن و بنياتنانى ئاسايى به هوّى لِيكوَّلِينهوه له ئاستى دادى كوّمهلاّيهتى و وانهوتنهوه و ناسنامهى قوتابيان.

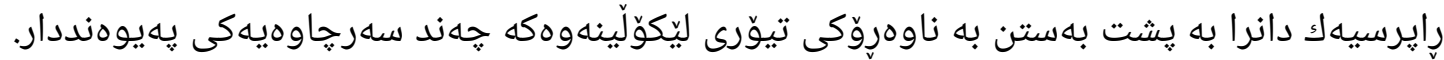
يرسيارى جهندى و جوّنى له بوجونى قوتايانكراون. 


\section{QALAAI ZANISTSCIENTIFIC JOURNAL}

A Scientific Quarterly Refereed Journal Issued by Lebanese French University - Erbil, Kurdistan, Iraq

Vol. (6), No (1), Winter 2021

ISSN 2518-6566 (Online) - ISSN 2518-6558 (Print)

بهشداربووهكان قوتابيانى قوّناغى جوارهمى بهشه مروّقايهتيهكانى زانكوّى سهلاحهديين. بوجونهكانيان يشتبيّبهستراون جونكه شارهزاى كيّشهانى سى سالّى رِابورديانن له كوّلِّز و بهشه زانستيه كانيان.

سهلمينرا و دهرجو كه فرمزمانهوانى له ئاستى راميارى و يّان كيشهيان نيه، كيشه له لايهنى جيّبه جيّكردن و كردايى ناو يوّلهكانى خويِندنه له تهكنيكهكان و وانه وتنهوه و فيّربوو. ئاستى بهكارهيّنان و فيّربوونى زمانه ئكاديميهكان يه كسان نيه. كه دهبيته هوّى نزمى ئاستى وهركرتن و فيّربوونى زانست زانياريهكانه لك يِيّويسته له يهيرهو و و

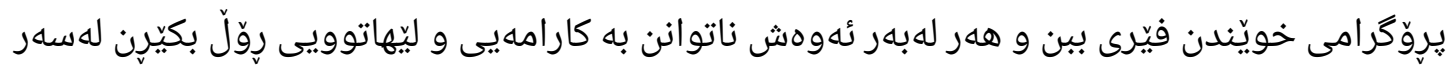
ئاستهكانه ناوجهيى و نيشتمانى و نيّنه تهوهيى.

\section{تأثثير التنوع اللفوي على أصول التدريس في بناء المعرفة}

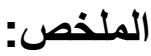

يشير التنوع اللغوي (LD) إلى التنوع اللغوي. هنا ، يشير إلى الاختلاف اللغوي الوظيفي اللغوي أو اللغوي الإئي

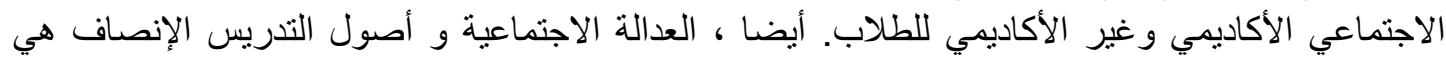
تمثيلات لتكافؤ الفرص التي تضمن التنمية المتساوية والمستمرة التي تؤدي إلى إعادة / بناء المعرفة.

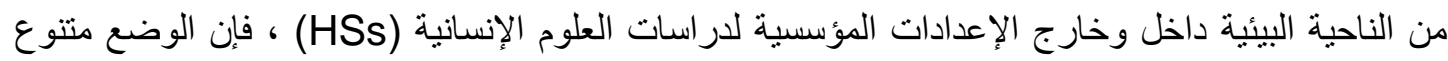

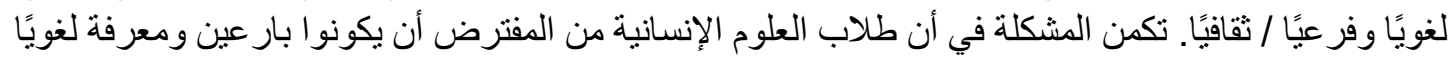

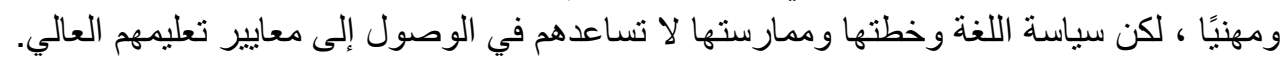

لذا فإن الأسئلة هي: هل ينم تنفيذ صعوبة التعلم بشكل صحيح؟ هل تؤدي صعوبة التعلم إلى إعادة بناء وتطوير

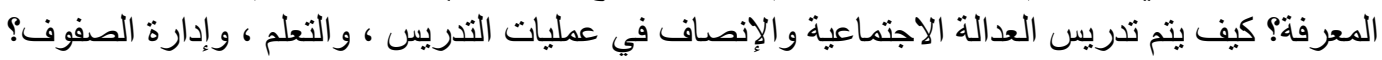
الفرضية هي أن صعوبة التعلم لا يتم تنفيذها كما هي ومتطلبات واحتباجات الطلاب. لذلك قد لا يتم إعداد الخريجين بمهارة و أكاديمية محليًا ووطنًا ودوليًا. لأنيًا.

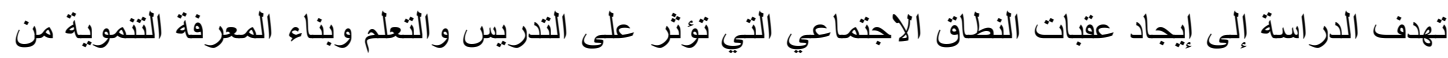

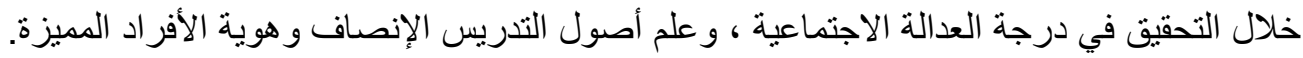




\section{QALAAI ZANISTSCIENTIFIC JOURNAL}

A Scientific Quarterly Refereed Journal Issued by Lebanese French University - Erbil, Kurdistan, Iraq

Vol. (6), No (1), Winter 2021

ISSN 2518-6566 (Online) - ISSN 2518-6558 (Print)

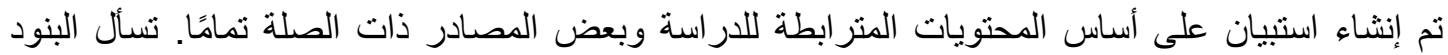
المواقف الكمية والنوعية ووجهات نظر الطلاب الكبار تجاه الموضوع.

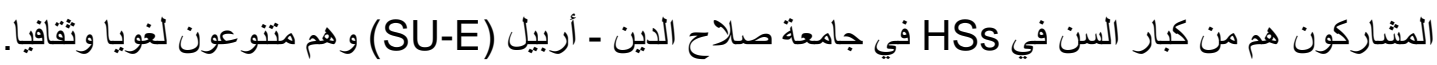

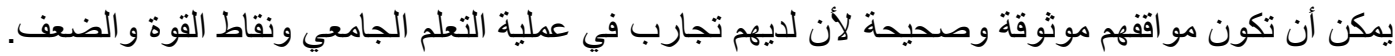

لقد تم التأكيد والاستتناج أن التطبيق الفعلي أو التطبيق العملي لصعوبة التعلم بتطلب تقنيات ذات صلة أكثر دقة

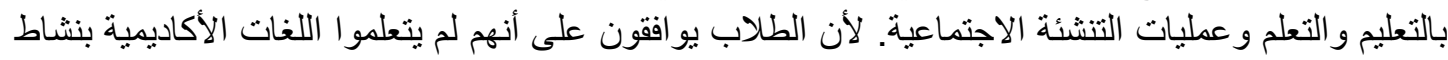

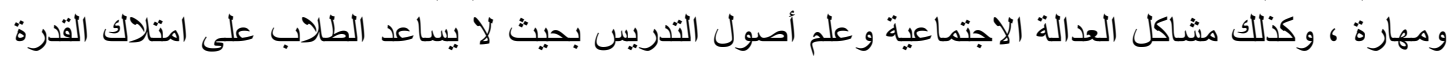

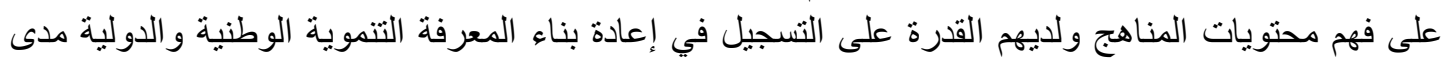
الحياة والإنشاءات الإبداعية ، ومهن التسويق ولاتهاء الكفاءات المهنية الأكاديمية. 